\title{
PANDANGAN ULAMA BALANGAN TENTANG PENGELOLAAN SUMBER DAYA ALAM BATUBARA DI BALANGAN DALAM PERSPEKTIF EKO-SUFISME
}

\author{
Ridhatullah Assya'bani* \& Ahmad Syadzali** \\ * Alumni Jurusan Akidah Filsafat Fakultas Ushuluddin dan Humaniora \\ IAIN Antasari Banjarmasin \\ **Dosen Jurusan Akidah Filsafat Fakultas Ushuluddin dan Humaniora \\ IAIN Antasari Banjarmasin
}

\begin{abstract}
It starts from a consciousness that how importance of the role of scholars in their assessments and views on social reality, particularly on the issue of environmental crisis that occurred to the people in Balangan regency. Based on the research, the writers found a classification of the scholars' views on coal mining and natural resources exploitation and the environmental impacts and social impact as the result. The first view, they agree fully to coal mining activities. Second view, they disagree on coal mining activity. The third view, the scholars who do not give a clear view or grey view to coal mining activities. Based the analysis conducted by the writers by using the eco-sufism concepts as theoretical basis, the writers concluded that their views who disagree with coal mining activity is based on the view of environmental ethics in accordance with the concept of eco-sufism.
\end{abstract}

Kata kunci: pandangan ulama, eco, tasawnf

\section{Pendahuluan}

Pada hakikatnya, dunia dan kehidupan ini merupakan perwujudan Tuhan bagi keberadaan diri-Nya, segala sesuatu yang ada di alam ini merupakan tanda (ayat) keagungan Allah sang pencipta. Dia menciptakan alam semesta dalam enam masa atau enam hari yang bila dihitung oleh manusia akan membutuhkan waktu miliyaran tahun. ${ }^{1}$ Firman Allah:

"Allah lah yang menciptakan langit dan bumi dan apa yang ada di antara keduanya dalam enam masa, kemudian Dia bersemayam di atas 'Arsy[1188]. tidak ada bagi kamu selain dari padanya seorang penolongpun dan tidak (pula) seorang pemberi syafa'at. Maka Apakah kamu tidak. memperbatikan?"

Kehidupan didunia ini sendiri tidak bisa dipisahkan dari keberadaan manusia dan lingkungan hidup di sekitarnya berupasumber daya alam seperti air, udara, binatang dan tumbuhtumbuhan. Tetapi, kalau kita menelaah asal mula manusia, kita akan mengetahui bahwa manusia berasal dari tanah kemudian Allah tiupkan ruh kedalamnya, sehingga jadilah ia seorang manusia. Itu artinya manusia adalah bagian tak terpisahkan dari alam. Namun manusia memiliki kelebihan yang sangat besar karena manusia memiliki kedudukan sebagai ciptaan Allah yang paling sempurna diantara makhluk-makhluknya yang lain dengan diberikan-Nya akal dan fikiran.

${ }^{1}$ Thalhah, Ahmad Mufid, Figh Ekologi Menjaga Bumi Memahami Makna Kitab Suci, (Yogyakarta: Total Media, 2008), h. 
Dengan akal dan fikirannya itu manusia diberikan-Nya kedudukan penting dalam kehidupan, yaitu untuk beribadah dan sebagai khalifah Allah di muka bumi. ${ }^{2}$

Sebagai khalifah, manusia memiliki kewajiban kolektif untuk memelihara bumi dari upayaupaya perusakan dan penghancurkan alam. Sebagai khalifah, manusia juga diberikan anugerah dan amanah untuk mengolah dan memanfaatkan sumber daya alam yang ada di darat dan di lautan untuk mendukung kelangsungan hidupnya dan memakmurkan bumi beserta para makhluknya. ${ }^{3}$ Allah berfirman:

"Dialah yang menjadikan bumi sebagai hamparan bagimu dan langit sebagai atap, dan Dia menurunkan air (bujan) dari langit, lalu Dia menghasilkan dengan hujan itu segala buab-buahan sebagai reqki untukmu; karena itu janganlah kamu Mengadakan sekutu-sekutu bagi Allab[30], Padahal kamu mengetabui."

Namun dalam usaha-usahanya manusia harus selalu mengedepankan prinsip keselarasan (mizan) dalam hidup, yaitu menjalani keseimbangan hidup dengan alam, karena segala sesuatu telah Allah susun dalam prinsip keseimbangan. Maka keseimbangan itulah yang akan menjaga keberlangsungan hidup seluruh makhluk di alam ini, kelangsungan para penghuninya termasuk manusia. ${ }^{4}$

Dalam konsep eko-sufisme, sangat ditekankan adanya keselarasan antara Tuhan, alam dan manusia.Konstruk pemikiran eko-sufisme digagas melalui adanya kesadaran untuk menjaga keseimbangan alam sebagai sebuah paradigma lingkungan berketuhanan, gagasan tersebut memuat dua pokok pemikiran.Pertama, bahwa kesadaran berlingkungan adalah bagian tidak terpisahkan dari kesadaran spiritual. Mencintai alam merupakan bagian dari mencintai Tuhan karena alam merupakan menifestasi dari Zat Tuhan. Alam semesta adalah Kalamullah. Karena ia adalah ayat al-Kauniyah yang sejajar dengan ayat qawliyah (al-Qur'an). Kedua, adanya upaya proses transformasi dari kesadaran spiritual menuju tataran implementasi. Berangkat dari kesadaran bahwa alam semesta adalah ayat al-Kauniyah yang sejajar dengan ayat qawliyab (alQur'an), maka seharusnya manusia memperlakukan alam semesta tidak ubahnya sebagaimana seorang hamba memperlakukan Kitabullah, yaitu disakralkan. Secara tidak langsungdapat dikatakan bahwa upaya kita untuk menjaga alam semestaadalah bagian bentuk ketakwaan kita kepada Allah SWT. ${ }^{5}$

Akan tetapi, tidak sedikit manusia yang mengenyampingkan arti dari keselarasan tersebut. Banyak individu ataupun kelompok yang berperilaku negatif dalam kehidupan sehari-hari sehingga mengganggu keseimbangan kehidupan alam dan kehidupan sosial secara umum. Misalnya, membuang sampah sembarangan, dan menggunakan teknologi untuk mengekplorasi sumber daya alam secara berlebihan. Perilaku negatif tersebut secara langsung maupun tidak langsung akan mengganggu keseimbangan alam semesta dan kehidupan. ${ }^{6}$ h. 29.

${ }^{2}$ Ibrahim Abdul-Matin, Greendeen Inspirasi Islam Dalam Menjaga dan Mengelola Alam, (Jakarta: Mizan, 2012), Cet. ke-1,

${ }^{3}$ Ulfah Utami, Konservasi Sumber Daya Alam perspektif Islam dan Sains, (Malang: UIN Malang Press, 2008), Cet. ke-1, h. 7.

${ }^{4}$ Rachmad K Dwi Susilo, Sosiologi Lingkungan, (Jakarta: Raja Grafindo Perkasa, 2008), h. 28.

${ }^{5}$ Suwito NS, Eko Sufisme, Konsep Strategi dan Dampak, (Purwokerto: Stain Press, 2011), h. 45.

${ }^{6}$ Amos Neolaka, Kesadaran Lingkungan, (Jakarta: Rineka Cipta, 2008), Cet. ke-1, h. 18. 
Manusia sering kali hanya berfikir untuk mengambil manfaat dan keuntungan yang sebesarbesarnya dari alam tanpa memperdulikan etika berlingkungan dan dampak negatifnya, akhirnya eksplorasi-eksplorasi yang berlebihan terhadap lingkungan terjadi di mana-mana, karena kekeliruan manusia dalam memahami konsep taskhir ${ }^{7}$

Efek ketidakseimbangan tersebutkemudianterjadi seperti banjir, gempa bumi, tanah longsor, kekeringan, dan buruknya kualitas udara mengingatkan kita secara langsung, bahwa segala perilaku manusia yang tidak bersahabat dengan alam akan mengakibatkanbencana,tidak hanya bagi manusia tapi juga bagi semua makhluk hidup yang bergantung kepada alam sekitar kita.8

Di Indonesia sendiri ekplorasi sumber daya alam sudah sangat luar biasa dan massive dilakukan, mulai dari penebangan hutan, pengeboran minyak, dan eksplorasi sumber daya alam yang dilakukan dengan besar-besaran yang kesemuanya itu tidak hanya memberikan dampak positif bagi bangsa Indonesia tetapi juga memberikan dampak menyakitkan seperti kasus banjir lumpur panas di Sidoarjo akibat pengeboran minyak oleh PT. Lapindo.9

Dalam konteks lokal Kalimantan Selatan, kondisi lingkungannya juga tidak lepas dari berbagai masalah, salah satu diantaranya adalah dampak kerusakan lingkungan akibat pertambangan batubara. Seperti yang termuat dalam harian Media Kalimantan Jum'at, 05 April 2013 yang menyatakan "Limbah Pertambangan Batubara PT. Adaro Indonesia yang Mencemari Lahan Masyarakat Seluas 6 Hektar Milik Warga Area Pertambangan" mengakibatkan kerusakan lahan dan merugikan masyarakat sekitarnya. Selanjutnya dalam Tribun Kalsel Banjarmasin Post Jum'at, 7 Juni 2013 juga menyatakan "Air Sungai Tabalong Kiwa Mendadak Keruh Diduga Tercemar Limbah Tambang Batubara di Bar-Tim".

Saat ini pertambangan batubara memang menjadi primadona bagi wilayah Kalimantan Selatan, khususnya Kabupaten Balangan yang notabene baru saja berdiri sendiri dan lepas dari Kabupaten Induknya Hulu Sungai Utara, sehingga menuntut pemerintahan yang ada untuk mencari berbagai sumber utama pendapatan daerah sendiri, karena tidak bisa dipungkiri keberadaan perusahaan batubara di suatu wilayah ikut memberikan sumbangsih besar bagi peningkatan pendapatan daerah dan perbaikan ekonomi masyarakat sekitarnya serta mendukung pengembangan pembangunan daerah. ${ }^{10}$

Namun di sisi lain, kita juga harus mengingat bahwa batubara merupakan energi yang tidak bisa diperbaharui dan kerusakan alam merupakan salah satu risikonya. Batubara merupakan salah satu kekayaan alam yang harus digunakan untuk kemaslahatan umat manusia, akan tetapi dalam pengambilan batubara itu harus dengan pengelolaan yang benar agar tidak menyebabkan terjadinya kerusakan lingkungan dan bencana alam. ${ }^{11}$

Hal ini sesuai dengan pasal 2 UU no 4 tahun 2009 tentang pertambangan Mineral dan Batubara yang menyatakan 7 asas hukum pertambangan yang meliputi; manfaat, keadilan,

\footnotetext{
${ }^{7}$ Taskhir secara literal berarti menundukkan, kemudian berkembang sebagai ekplorasi alam.Tim Peneliti, Eko-Teologi Al-Qur'an "Sebuah Kajian Tafsir dengan Pendekatan Tematik", (Banjarmasin; IAIN Antasari Banjarmasin, 2012), h. 7.

${ }^{8}$ Tresna Sastrawijaya, Pencemaran Lingkungan, (Jakarta, Rineka Cipta, 2009), hal 39.

${ }^{9}$ Ulfah Utami, Konservasi Sumber Daya Alam perspektif Islam dan Sains, h. 7.

${ }^{10}$ Sukarni, Fiqh Lingkungan Hidup Perspektif Ulama Kalimantan Selatan, (Jakarta; Kementrian Agama RI, 2011), h. 3.

${ }^{11}$ Tim Peneliti PP Muhammadiyah, Teologi Lingkungan "Etika Pengelolaan Lingkungan Dalam Perspektif Islam", (Yogyakarta; Kementrian Lingkungan Hidup, 2011), h. 16.
} 
keseimbangan, keberpihakan kepada kepentingan bangsa, partisifatif, transparansi, akuntabilitas serta berkelanjutan dan berwawasan lingkungan. ${ }^{12}$

Ini yang kemudian disorot dalam sebuah pemberitaan media surat kabar sebagai berikut: "Masyarakat Kalsel harus bersiap-siap. Selain menghadapi kerusakan alam, juga kehabisan batubara."

Kalimat tersebut mengawali berita Banjarmasin Post edisi Kamis, 26 Maret 2011 dengan judul "30 Tahun Lagi, Impor batubara”. Dalam berita yang dimuat di halaman 16 tersebut, Hersonyo P. Wibowo, Wakil Direktur Pembinaan Pengusahaan Batubara Kementerian ESDM, menyatakan bahwa cadangan batubara di Indonesia sebanyak 28 miliar ton, dalam waktu tidak sampai 30 tahun ke depan akan habis. Hal ini disebabkan oleh produksi dan eskpor batubara yang semakin tahun semakin meningkat.

Apa yang dinyatakan oleh Hersonyo di atas patut menjadi pemikiran kita bersama. Hal ini mengingat bahwa "emas hitam" tersebut merupakan salah satu aset Kabupaten Balangan yang cukup penting dan mencakup lahan yang cukup banyak. Kondisi alam di Kabupaten Balangan mau tidak mau akan berubah dari waktu ke waktu. Bumi yang dahulunya hijau niscaya akan berubah menjadi tanah lapang dengan lubang, jika tidak diperhatikan dan dilakukan kendali bersama, ditambah lagi ketika lahan berkurang pertumbuhan generasi baru juga terus bertambah. Maka kala generasi penerus diwarisi alam sudah tidaklagi "manis," kandungan buminya juga habis.

Ulama sebagai bagian dari masyarakat Balangan sekaligus sebagai pembuat opini dan penggerak sosial moral masyarakat memiliki bagian penting dalam melihat persoalan kerusakan alam di Kalimantan Selatan khususnya Kabupaten Balangan. Ulama harus berperan danambil bagian terhadap persoalaan-persoalan alam serta memberikan kontribusinya, baik langsung berhubungan dengan para pengusaha atau dengan pemerintah. Karena ulama memiliki pengetahuan agama yang menyadari betapa besarnya hubungan antara Tuhan, manusia dan alam. Ulama juga merupakan wakil rakyat dan persentasi masyarakat dalam memahami persoalan yang sedang terjadi. Oleh karena itu, ulama diharapkan untuk dapat memberikan kontribusinya dalam persoalan seperti ini, karena ulama mampu memberikan dan mengemukakan pandangannya serta menyalurkan aspirasi masyarakat kepada pemerintah dan karena ulama merupakan tokoh yang menjadi panutan masyarakat, mempunyai wawasan agama yang luas dan mengerti keadaan masyarakat yang ada di lingkungannya. Oleh karena itu, pandangan ulama sangat berperan penting dalam melihat masalah kerusakan alam.

Ulama sebagai tokoh masyarakat yang memiliki wawasan luas tentang keagamaan dan memiliki pemahaman agama yang baik. Seharusnya mengerti dengan keadaan masyarakat sekitar, tetapi apakah ulama sudah memposisikan dirinya sebagaimana yang diharapkan masyarakat, ini yang perlu pengkajian. Bagaimana kenyataannya pandangan ulama melihat persoalan ini. 


\section{Landasan Teori}

Eko-Sufisme terdiri dari dua kata yaitu eko dan sufisme.Secara bahasa atau etimologis, kata eco berasal dari kata oeco (Latin) yang berarti kampung, dan oikos (Yunani) yang berarti rumah atau tempat tinggal. Kata ini mengalami pergeseran makna dari rumah sebagai kediaman keluarga menjadi lingkungan hidup sebagai kediaman manusia. ${ }^{13}$ Kata ecology pertama kali digunakan pada tahun 1866 oleh seorang ahli biologi bernama Haeckel. Namun demikian, kata ini belum menjadi konsep yang matang hingga kemudian disempurnakan oleh ahli botani berkebangsaan Denmark, Warming.

Secara istilah atau terminologis ekologi diartikan dengan "The comprehensive science of the relationship of the organism to environment" atau sebuah ilmu yang mempelajari interaksi antara makhluk hidup dan lingkungannya. Sebagai sebuah ilmu pengetahuan ekologi memiliki empat pokok bahasan utama yang pertama individu atau organisma, yang keduapopulasi, dan komunitas, yang ketiga ekosistem, dan yang keempat biosfir. ${ }^{14}$

Secara istilah atau terminologis sufi atau sufisme dipahami sebagai sebuah sikap untuk menenangkan diri dari fenomena kehidupan yang serba materialistis. Sufisme dianggap sebagai sebuah sistem moral atau etika dalam menjalani kehidupan didunia berdasarkan ajaran dasar Islam dan Sunnah Nabi Muhammad yang terkenal zuhud atau sederhana. ${ }^{15}$

Ketika Islam berkembang dan banyak orang memeluk Islam, terjadilah perkembangan strata sosial sehingga terjadi penyelewengan ajaran orisinal Islam. Dimana pada masa itu, umat Islam terperangkap dalam penyakit hati dan sosial seperti maraknya kerakusan para pejabat yang asosial serta korupsi yang terjadi dimana-mana, kemudian munculah gerakan untuk memperbaharui kerohanian umat muslim dengan ajaran-ajaran yang menganjurkan pengikutnya untuk mengurangi makan, menjauhkan diri dari keramaian dunia dan mencela dunia. ${ }^{16}$

Sufisme juga membendung pendangkalan ajaran agama dan formalisme dalam melaksanakan syariat agama yang lebih bercorak fiqh dan mengajarkan orang untuk lebih memelihara jiwa dan kemurnian hati serta mengarah pada psiko-moral yang diarahkan kepada tingkah laku serta hal-hal yang bersifat metafisik. Sufisme juga berusaha menjembatani antara manusia dan lingkungannya sehingga tercipta kehidupan yang harmonis antara manusia dengan manusia lainnya dan antara manusia dan lingkungan dimana mereka berada. ${ }^{17}$

Konsep eko-sufisme dipahami sebagai sebuah dimensi mistik Islam yang menitikberatkan pada pola relasi yang etis dan estetik antara manusia dengan Tuhan, serta antara manusia dengan lingkungannya.Dalam konteks ini, Islam sebagai basis sufisme memandang bahwa semua ciptaan memiliki manfaat dan diadakan tanpa kesia-sian. ${ }^{18}$

\footnotetext{
${ }^{13}$ W.J.S. Poerwadarminta, Kamus Umum Bahasa Indonesia, (Jakarta: Balai Pustaka, 2007), h. 312. Juga Lihat Fahruddin M Mangunjaya, Ed, Menanam Sebelum Kiamat, Islam Ekologi dan Gerakan Lingkungn Hidup, (Jakarta; Yayasan Obor Indonesia, 2007), h. 4.

${ }^{14}$ Suwito NS, Eko-Sufisme "Konsep, Strategi dan Dampak", (Purwokerto: STAIN Press, 2011) cet. II, h. 33. Lihat Pula Saifullah, Hukum Lingkungan, Paradigma Kebijakan Krimimal di Bidang Konservasi Keanekagaraan Hayati, (Malang, UIN Malang Press, 2007), h. 13.

${ }^{15}$ Ahmad Bangun Nasution dan Riyani Harum Siregar, Akblak Tasawnf, (Jakarta; Raja Grafindo Perkasa, 2013), h. 4-7.

${ }^{16}$ Amin Syukur dan Masyharuddin, Intelektualisme Tasawnf, (Yogyakarta, Pustaka Pelajar, 2002), h. 11.

${ }^{17}$ Ali Maksum, Tasawnf Sebagai Pembebasan, (Yogyakarta; Pustaka Pelajar, 2003), h. 70.

${ }^{18}$ Seyyed Hossein Nasr, Pengetahuan dan Kesucian, (Yogyakarta; Pustaka Pelajar, 1997), h. 220-223.
} 
Eko-sufisme adalah konsep baru sufi yang dikonstruk melalui penyatuan kesadaran antara kesadaran berlingkungan dan berketuhanan dengan dua prinsip utama yaitu pertama, kesadaran berlingkungan adalah bagian tak terpisahkan dari kesadaran spiritual bahwa mencintai alam semesta merupakan bagian dari mencintai Tuhan karena mencintai sesuatu yang menjadi milik Tuhan merupakan bagian dari mencintai Tuhan. Kedua, mengupayakan adanya proses transformasi dari kesadaran spiritual menuju kesadaran ekologi dengan tujuan keserasian semesta dan keserasian antara perilaku sufi dan Tuhan. Kondisi ini yang kemudian membuahkan cinta timbal balik antara manusia dengan Tuhan, manusia dengan manusia dan manusia dengan alam semesta.Etika eko-sufisme mendorong perilaku manusia hidup selaras dengan Allah dan alam. ${ }^{19}$

\section{a. Konsep Eko-Sufisme}

Jika dalam konteks ekologi Barat pembicaraan tentang etika dan estetika relasi dalam diskursus ekosistem luput dalam pembahasan karena seringkali terfokus pada potensi alam sebagai produsen dan konsumen, atau penyedia dan pemangsa.

Maka dalam tradisi sufi mereka justru memiliki pandangan yang lebih maju dan holistik, dimana dalam tradisi sufi alam semesta tidak hanya berfungsi sebagai penyedia kebutuhan manusia secara fisik melainkan juga sebagai Ayat tanda kebesaran Tuhan dan media untuk mendekatkan diri dan syukur atas segala nikmat yang telah diberikan-Nya. ${ }^{20}$

Menurut Nasr, meskipun kosmos manusia memiliki hukum-hukum dan ritmenya yang bisa dipahami lewat fisika modern. Namun sayangnya, dengan berkembangnya sains modern, manusia mulai meninggalkan sisi metafisik diri mereka sendiri, sehingga manusia kehilangan harmoninya dengan alam dan signifikansi tertentu di antara simbol-simbol kosmologi yang menghubungkan mereka dengan kehadiran suci Tuhan dalam tatanan realitas sebagai sebuah teofani diantara ruang dan waktu yang membatasi manusia dari Tuhannya yang tidak memilki batas baik dalam ruang dan waktu. ${ }^{21}$

Sains modern dan kaki tangannya teknologi telah mendapatkan kritik yang begitu banyak karena penyangkalannya terhadap realitas kosmologis ketuhanan di alam semesta. Manusia modern menurut Nasr sedang hidup dipinggiran lingkaran eksistensinya, mereka hidup semu dan tidak lagi otentik mereka terjauh dari kesejatian dan memiliki jurang keterpisahan diri dari titik eksistensi dengan sang pemilik eksistensi.

Hilangnya kosmologi riil dalam ilmu pengetahuan Barat secara umum dikarenakan oleh pengabaian terhadap metafisika dan kegagalan untuk mengingat adanya hirarki keberadaan dan pengetahuan.Metafisika juga seringkali direduksi menjadi filsafat yang rasionalistik dan secara perlahan sekedar dijadikan sebagai tambahan bagi sains-sains alam dan matematis.

Menurut Nasr pengabaian terhadap konsepsi sains dan kegagalan untuk memahami arti sebenarnya dari kosmologi sains alam kuno dan zaman pertengahan, sebagian besar ditimpakan pada cara mempelajari sains saat ini. Penelitian sains lebih dimaksudkan untuk mengagungkan

\footnotetext{
${ }^{19}$ Lihat juga Seyeed Hossein Nasr, The Garden of Truth, (Bandung; Mizan Pustaka, 2010), h. 45.

${ }^{20}$ Mulyadhi Kartanegara, Nalar Religius, Memahami Hakikat Tuban, Alam, dan Manusia, (Jakarta; Penerbit Erlangga, 2007), h. 2-3.

${ }^{21}$ Lihat Juga Bayraktar Bayrakli, Eksistensi Manusia, (Jakarta; Perenial Press, 2000), h. 11.
} 
sains modern dan akar sejarahnya ketimbang melakukan studi secara mendalam tentang konsepsi alam. ${ }^{22}$

Hilangnya pengetahuan metafisik adalah penyebab hilangnya harmoni antara manusia dan alam, dengan kuatnya pola pikir materialisme menyebabkan peran ilmu metafisik kehilangan signifikansinya dari kerangka pengetahuan Barat sehingga pengetahuan tentang dunia eksternal akhirnya tidak lebih merupakan pengetahuan semu tentang diri sendiri. Manusia dengan sains yang mereka miliki saat ini terpish dengan alam dan kosmologis, sehingga mereka kehilangan puncak pengetahuan, yakni kebebasan dan batasan dalam manifestasi Tuhan terhadap realitas alam semesta. ${ }^{23}$

Pemahaman Nasr tentang alam sebagai simbol manifestasi Tuhan tidak bisa dilepaskan dari pemahamannya tentang Islam.Menurutnya secara universal ada tiga level makna Islam.Pertama, bahwa semua makhluk berada dalam kepatuhan atau berserah kepada Tuhan.Kedua, semua manusia yang menerima kehendak hukum suci Tuhan sesuai fitrah adalah muslim. Dan ketiga, kearifan (gnostic) adalah sifat muslim yang tertinggi. Gnostic adalah cara pandang yang menekankan kesatuan bersama alam dan memahami alam dari dalam. ${ }^{24}$

Islam menurut Nasr dengan sepenuhnya menolak memisahkan manusia dan alam dan mempertahankan pandangan integral tentang alam semesta dan melihat dalam urat nadi keteraturan alam dan kosmos dalam sebuah arus rahmat Ilahi. Manusia tidak dapat menentang latar belakang alam yang profane dan berhadapan dengan rahmat Tuhannya. Manusia harus berusaha mentrandensi alam dan alam sendiri membantu proses ini asalkan manusia dapat belajar merenungkan alam dan tidak menjadikannya sebagai sebuah wilayah yang terpisah dari realitas, tetapi sebuah cermin yang memantulkan realitas tertinggi, sebuah panorama simbol tidak terbatas yang berbicara pada manusia dan memberikan makna padanya. ${ }^{25}$

Sebenarnya maksud dan tujuan penciptaan bagi Tuhan adalah untuk mengetahui diri-Nya melalui instrument pengetahuan-Nya yang sempurna. Maka manusia menduduki posisi tertentu di dunia ini, ia berada diporos dan pusat kosmos, penjaga sekaligus penguasa alam. Manusia adalah salurah rahmat bagi alam melalui partisipasi aktifnya di dunia spiritual yang akan memberi cahaya ke dalam alam dunia. Apabila tidak ada lagi pelaku kontemplasi dan orang suci, alam akan kehilangan cahaya yang meneranginya dan udara yang menghidupinya, itulah mengapa ketika keadaan batin manusia telah berpaling pada kegelapan dan kekacauan, alam juga berpaling dari harmoni dan keindahan untuk jatuh kedalam ketidakseimbangan dan kejahatan. Manusia yang menjalani hidup hanya dipermukaan keberadaannya hanya akan mempelajari alam sebagai sesuatu untuk dimanupulasi dan didominasi. Hanya dengan beralih ke dimensi batin dari keberadaannya, manusia dapat melihat alam sebagai sebuah simbol realitas yang transparan sehingga dapat mengetahui dan memahami alam menurut arti yang riil. ${ }^{26}$

\footnotetext{
${ }^{22}$ Seyyed Hossein Nasr, Intelektual Islam, Teologi Filsafat dan Gnosis, (Yogyakarta; Pustaka Pelajar, 1991), h. 69-84.

${ }^{23}$ Majelis Lingkungan Hidup PP Muhammadiyah, Akblak Lingkungan, Panduan Berprilaku Ramah Lingkungan, Jakarta; PP Muhammadiyah, 2011), h. 40.

${ }^{24}$ Seyyed Hossein Nasr, The Heart of Islam: Enduring Value for Humanity. diterjemahkan oleh Nurasiah Fakih Sutan Harahap, The Heart of Islam "Pesan-Pesan Universal untuk Kemanusiaan, (Bandung; Mizan Pustaka, 2003), h. 13.

${ }^{25}$ Mudhofir Abdullah, Al-Qur'an dan Konservasi Lingkungan, (Jakarta; Penerbit Dian Rakyat, 2010), h. 38.

${ }^{26}$ Seyyed Hossein Nasr, Antara Tuban, Manusia dan Alam,(Yogyakarta; IRCiSoD, 2003), h.31.
} 
Konsep etika lingkungan sufi yang dikenalkan oleh Seyyid Hossein Nasr adalah berdasarkan pengalaman dan pemahamannya akan negasi dan penyangkalan manusia terhadap alam secara spiritual sehingga mengangap dunia eskatologis sebagai sesuatu yang tidak riil dan landasan ajaran agama yang merupakan tujuan bagi batin manusia yang sapiensal menjadi sesuatu yang usang sebagaimana pandangan kaum komunis yang pada giliraannya membantu terciptanya pengrusakan dan penghancuran di alam ini atas nama logika ilmiah. ${ }^{27}$

Dalam tradisi sufi seorang yang hendak memahami makna hidup diharuskan untuk membersihkan dan menggunakan hati sebagai sebuah cermin untuk mengetahui perjalanan spiritual sehingga ia menemukan dirinya sendiri, alam semesta dan berbagai macam bentuk kehidupan yang ada didalamnya adalah lambang bagi sifat-sifat sang Ilahi. Diskursus tentang Tuhan dan alam menjadi suatu yang sangat urgen pagi para pesuluk dalam mencapai tingkatan tertinggi jiwanya. Terdapat berbagai macam dan penjelasan kaum sufi dan mistiko-sufistik terhadap bagaimana singgungan-singgungan dan koneksi antara satu partikel di alam semesta seperti teori iluminasi (isyrâqi), 2) teori manifestasi (tajalli), 3) bikmah muta'alliyah, 4) teori atomistik. Berbagai macam pendapat dan penjelasan tentang bagaimana hubungan alam Tuhan dan manusia itu adalah bukti sahih dari sakralisasi agama Islam dan kaum sufi terhadap alam semesta. ${ }^{28}$

Namun pada dasarnyasemua teori tentang Tuhan, alam, serta hubungan antara alam dan Tuhan dalam sufisme dijelaskan bahwa alam semesta merupakan sesuatu yang bersifat suci karena alam semesta merupakanciptaan dan cerminandari sifat-sifat Tuhan atau teofani Tuhan.Jika merusak ciptaan seseorangsama dengan menyakiti hati orang yang menciptakan. Maka dalam konteks lingkungan, merusak alam semesta atau lingkungan sama dengan menjauh dan membangkang dengan perintah Tuhan. ${ }^{29}$

Disinilah peran penting dan kontribusi Nasr dalam pemikiran modern, berangkat dari kesadaran dan kegelisan hatinya terhadap realitas manusia modern yang makin jauh dari ajaran sakral agama baik dalam hal ritus ibadah maupun substansi ajaran, ia kemudian menggagas sebuah konsep yang dia sebut dengan tawhid atau teologi lingkungan.

Konsepnya menyatakan bahwa realitas atau wujud yang ada adalah satu. Realitas termasuk didalamnya alam semesta, manusia, binatang, dan tumbuh-tumbuhan serta semua yang ada termasuk Tuhan.Nasr menganalogikan konsepnya ini dengan sebuah buku yang terdiri dari lembaran-lembaran yang terdiri dari huruf-huruf.Huruf adalah simbol yang tertulis secara beragam.Meski beragam simbol huruf tersebut berasal dari hakikat yang satu yaitu realitas. ${ }^{30}$

Teori Nasr tentang kosmos ini selaras dengan The String Theory yang dikemukakan oleh Greene yang menjelaskan bahwa setiap partikel dasar tersusun dari sebuah senar dan setiap senar adalah indentik.Perbedaan partikel-partikel timbul karena masing-masing senar mengalami pola getaran resonan yang berbeda-beda.Jika kita lihat alur fikir tawhid Nasr, kemungkinan besar gagasannya terpengaruh oleh ide-ide wahdatul wujud Ibn Arabi. ${ }^{31}$

\footnotetext{
${ }^{27}$ Majelis Lingkungan Hidup PP Muhammadiyah, Teologi Lingkungan, Etika Lingkungan dalam Perpektif Islam, (Jakarta; PP Muhammadiyah, 2011), h. 23.

${ }^{28}$ Drajat Amroeni, Subrawardi "Kritik. Filsafat Prepatitik”, (Yogyakarta; LKIS, 2005), h. 226.

${ }^{29}$ Seyyed Hossein Nasr, The Heart of Islam, Pesan-pesan Universal Islam Untuk Kemanusiaan, hal, 13.

${ }^{30}$ Aan Rukmana, Seyyed Hossein Nasr, Penjaga Taman Spiritualitas Islam, (Jakarta; Dian Rakyat, 2013), h. 80.

${ }^{31}$ Yunasril Ali, Manusia Citra Ilah, Pengembangan Konsep Insan kamil Ibn Arabi oleh Al-Jilli, Jakarta; Penerbit Paramadina, 1997), h. 51.
} 
Nasr memandang antara al-Qur'an dan alam semesta memiliki kesamaan wujud. Jika alQur'an adalah wahyu yang diturunkan dengan berbagai simbol tulisan dan kata yang terhimpun.Maka alam semesta adalah wahyu yang diciptakan dengan bentuk kosmik, alam semesta adalah buku yang berisi wahyu primordial yang mana itu berarti bahwa alam semesta dan al-Qur'an adalah "kitab suci" Tuhan untuk manusia.

Alam merupakan perwujudan dari realitas yang tertinggi karena struktur alam mengandung sebuah pesan spiritual bagi manusia yang menjadikan manusia lebih dekat dengan Tuhan dan dengan demikian alam merupakan sebuah wahyu yang sumber asalnya adalah sama dengan agama itu sendiri yaitu dari Tuhan. ${ }^{32}$

Alam adalah tempat suci yang di dalamnya terdapat makna tertinggi orang beragama Islam untuk melaksanakan kewajiban sebagai hamba Tuhan, yaitu untuk melaksanakan kewajiban shalat lima waktu, selain itu alam juga merupakan sumber dan sarana untuk memperoleh pengatahuan mengenai hikmah Tuhan. ${ }^{33}$ Dengan merenung (tafakur) dan memikirkan alam akan mengetahui makna hikmah Tuhan yang tersirat dalam alam semesta. Hal ini diterangkan dalam al-Qur'an:

"Kami akan memperlihatkan kepada mereka tanda-tanda (kekuasaan) Kami di segala wilayah bumi dan pada diri mereka sendiri, bingga jelas bagi mereka babwa Al Quran itu adalah benar.Tiadakah cukup bahwa Sesunggubnya Tubanmu menjadi saksi atas segala sesuatu?”

Melihat alam dengan mata hati bukan hanya dipahami sebagai realitas (wujud) benda kasar, tetapi sebagai kenyataan kebesaran Tuhan yang ada pada alam dan kenyataan itu merupakan tercermin sifat-sifat Ilahi. Alam adalah ribuan cermin yang memantulkan wajah Ilahi.Melihat alam sebagai teofani ${ }^{34}$ adalah melihat cerminan Tuhan dalam alam yang beraneka ragam. Alam sebagai pendukung kehidupan spiritual, dengan menggali hikmah yang tersirat dibalik alam semesta akan terungkap rahasia-rahasia Ilahi.

Didalam Islam hubungan antara manusia, kosmos dan kitab suci adalah sentral dari agama secara luas. Kitab suci Islam adalah al-Qur'an yang tertulis dan tersusun sebagaimana ayat-ayat Allah di alam raya ini. Semua itu adalah kitab suci dan manifestasi dari kekuasaan dan keberadaan Allah.Dalam perkembangannya ayat dari kitab suci dan ayat dari kosmos yang keduanya diciptakan Allah untuk melahirkan makna batin bagi manusia, sehingga membantu manusia untuk menemukan hakekat dirinya sendiri.

Konsep eko sufisme sendiri adalah kajian baru dalam ilmu pengetahuan khususnya filsafat, kajian ini muncul sebagai penyikapan positif terhadap realitas kehampaan hidup manusia saat ini.Manusia pada dasarnya berada antara ciptaan spiritualzzzz dan material dan memiliki sifat keduanya.Dalam diri manusia terdapat seluruh ciptaan dalam arti esensial. Manusia diciptakan menurut gambar Tuhan, namun sebagai binatang, disatu sisi ia merupakan pancaran dunia spiritual dan disisi lain ia merupakan pancaran dunia binatang. Nasib manusia erat tidak terpisahkan dari dunia alam dan spiritual.

\footnotetext{
${ }^{32}$ Seyyed Hossein Nasr, Antara Tuhan, Manusia dan Alam, h.31.

${ }^{33}$ Seyyed Hossein Nasr dan Oliver Leman, Ensiklopedi Tematis Spiritualitas Islam, (Bandung, Mizan, 2003), h. 472.

${ }^{34}$ Teofani berarti Tuhan menampakkan diri-Nya dengan tanda-tanda yang dapat dihayati oleh yang manusia, sehingga mereka sadar bahwa mereka langsung berhadapan dengan Tuhan mereka sendiri.
} 
Manusia tidak hanya berdiri pada titik perpotongan antara sumbu-sumbu vertikal dan horizontal dari eksistensi yang berada dalam simbolisme spansial mereka, namun juga hidup pada suatu masa antara keabadian dan temporal tertentu. Tidak ada bukti yang lebih baik yang diperlukan dalam mempertemukan dimensi-dimensi waktu dan keabadian di dalam diri manusia daripada kenyataan bahwa manusia menyadari akan kematiannya sendiri, mortalitasnya sendiri, yang berarti dia juga diberi kemungkinan untuk menggambarkan bahwa yang terbentang dibalik batas akhir eksistensi teresterial. Ajaran-ajaran agama diseluruh dunia penuh dengan referensi dengan hubungan antara manusia, waktu dan keabadian.Keduanya dalam manusia dan dalam tatanan objektif, karena semua agama dihubungkan dengan kesucian dan waktu juga dihubungkan dengan keabadian dan bagi keabadian kesucian adalah tanda bagi keberadaanya.

Disinilah letak penting konsep perennial yang diterapkan oleh Nasr yang dianggapnya terdiri dari prinsip-prinsip suci termasuk didalamnya agama, filsafat dan seni yang merupakan suatu yang meski terpisah-pisah tetapi menyatu dalam sebuah konsep keabadian dan kesucian dimana manusia sempurna secara rohani akan mampu menghargai keabadian dan kesucian agama, ilmu, seni dan lingkungan yang pada hakikatnya adalah simbol keberadaan Tuhan.

Konsep eko sufisme adalah salah satu jembatan yang menghubungkan antara keberadaan manusia dan keberhakkan dirinya dalam mengekplorasi dan mengekspoitasi alam untuk kemaslahatan dirinya dengan sebuah keharusan untuk tetap terus menjaga keabadian dan kesucian perennial alam raya yang menjadi teofani Tuhan. ${ }^{35}$

\section{b. Penerapan Eko-Sufisme Dalam Kehidupan}

Manusia ialah makhluk Tuhan yang sempurna karena memiliki akal pikiran dan hati yang membuat manusia mempunyai aspek yang tidak dimiliki oleh makhluk lainya yaitu kesadaran akan dirinya sehingga dengan kelebihan yang dimilikinya itu ia ditugaskan sebagai khalifah Tuhan di bumi. ${ }^{36}$

Sebagai khalifah berarti manusia merupakan perantara utama dalam hubungan antaraTuhan sebagai sang pencipta dan alam serta makhluk-makhluk Tuhan yang lainnya, dengan kesadaran sebagai khalifah inilah manusiadituntut untuk bertindak arif dan bijaksana dalam mengelola alam semesta dan lingkungan. ${ }^{37}$

Dengan konsep eko-sufisme yang berdasarkan pada hubungan antara Tuhan, manusia dan alam yang menjadikan alam semesta sebagai media dan sarana untuk sampai kepada Tuhan manusia diharapkan mampu mengelola alam berdasarkan konsep-konsep yang ada dalam sufisme sehingga manusia memperoleh kesadaran spiritual. ${ }^{38}$

Aplikasi tasawuf dalam perspektif lingkungan antara lain dengan fikr (merenung) tandatanda kekuasaan Allah yang terhampar di alam semesta. berati secara tidak langsung kita ziker (ingat) kepada Allah. ${ }^{39}$ Dengan perenungan yang mendalam tentang ciptaan Tuhankemudian

\footnotetext{
${ }^{35}$ Sachiko Murata, The Tao Of Islam, (Jakarta; Penerbit Mizan, 2000), h. 47.

${ }^{36}$ Seyyed Hossein Nasr, Islamic Spirituality Foundations. diterjemahkan oleh Rahmani Astuti, Ensiklopedi Tematis Spiritualitas Islam, (Bandung, Mizan, 2003),h. 482.

${ }^{37}$ Seyyed Hossein Nasr, Living Sufism. diterjemahkan oleh Abdul Hadi WM, Tasawnf Dulu dan Sekarang, (Jakarta: IKAPI, 2000), cet. 4, h. 37.

${ }^{38}$ Aan Rukmana, Seyyed Hossein Nasr "Penjaga Taman Spiritualitas Islam", h. 46.

${ }^{39}$ Suwito NS, Eko-Sufisme (Konsep, Strategi dan Dampak), (Puworkerto: STAIN Press, 2011), h. 47.
} 
akan memberikan wawasan kepada seorang hamba tentang relasi Tuhan, alam dan manusia yang sangat erat dan menghormati alam semesta sebagai sebuah ciptaan Tuhan merupakan sebuah keniscayaan.Karena tidak ada yang sia-sia dalam ciptaan Tuhan, dan semua memiliki mata rantai ekologis yang yang membantu keharmonisan kehidupan di alam semesta.Ziker dan fikr tersebut kemudian akan menghasilkan kearifan-kearifan batin, yang akan mempengaruhi perilaku dalam keseharian kita. ${ }^{40}$

Kemudian, konsep zuhd yang melatih diri seseorang agar tidak terlalu berlebihan dalam mengonsumsi dan menggunakan sesuatu yang sifatnya material.Zubd bukan hanya sebuah konsep dan sikap mental yang menjadi pandangan hidup, akan tetapi sebuah perwujudan dalam kehidupan yang sangat penting untuk menekan laju angka konsumsi dan produksi yang sifatnya berkelanjutan dalam jangka waktu yang panjang. Dengan bertambahnya jumlah penduduk akan memberikan konsumsi yang terus meningkat terhadap sistem pendukung lingkungan. Tuntutan manusia terhadap lingkungan yang semakin besar akan menimbulkan degradasi tanah, kerusakan akibat polusi, hilangnya keanekaragaman hayati dan penggundulan hutan yang semakin meluas. ${ }^{41}$ Sikap zuhd yang diaplikasikan dalam kehidupan sehari-hari akan menetralisir perilaku konsumtif manusia yang berlebihan dan membawa manusia untuk hidup dalam kesederhanaan yang mana pada gilirannya akan memberikan jalan bagi konservasi lingkungan demi terciptanya pelestarian alam.

Selain konsep ziker, fiker dan zubd, ada sebuah konsep tasawuf yang erat kaitannya dengan Tuhan, yaitu bub atau mahabbah (kecintaan). ${ }^{42}$

Meskipun kecintaan bermula ditujukan kepada Tuhan, tetapi suatu saat ia akan memanifestasikan dirinya dalam cinta kepada diri seseorang, sesama dan lingkungan. Dari sinilah bubb mendapatkan tempat untuk dapat dibawa dalam kearifan lingkungan. Cinta kepada Tuhan akan mempengaruhi pada cinta semua kebaikan, keadilan, kasih sayang, kebenaran dan akhirnya termasuk mencintai lingkungan.

Dalam konteks ekologi yang berbasis tasawuf, kerusakan/merusak alam sama dengan merusak kehidupan sekaligus merusak sarana ma'rifat. Dengan kata lain, dalam konsep ekosufisme, keberadaan alam sekitar menjadi sesuatu sangat penting dalam keberadaannya yang harus dipelihara dan dilestarikan, karena dia adalah sumber kehidupan dan pengetahuan (ilmu, ma'rifat). Merusak alam sama halnya dengan menutup pintu ma'rifat. ${ }^{43}$

Selain metode-metode tasawuf diatas, eko-sufisme juga menyediakan etika dasar dan pijakan spiritual berbasis agama Islam dalam mengelola lingkungan, etika pengelolaan lingkungan ini mesti ditanamkan dalam diri manusia.Adapun prinsip etika tersebut, prinsippertama, segala isi alam semesta adalah ciptaan dan milik Allah. ${ }^{44}$ Sebagaimana yang telah dijelaskan dalam al-Qur'an:

"Kepunyaan Allab-lah segala apa yang ada di langit dan apa yang ada di bumi..."

\footnotetext{
${ }^{40}$ Sukarni, Fikih Lingkungan Hidup Perspektif Ulama Kalimantan Selatan, (Jakarta: Kementrian Agama RI, 2011), cet. 1, h. 219.

${ }^{41}$ Sukarni, Fikih Lingkungan Hidup Perspektif Ulama Kalimantan Selatan, h. 218.

${ }^{42}$ Ali Yafie, Merintis Fiqh Lingkungan Hidup, (Jakarta; Yayasan Amanah, 2006), h. 157.

${ }^{43}$ Harun Nasution, Filsafat dan Mistisme Dalam Islam,(Jakarta; PT Bulan Bintang,1990), h. 70.

${ }^{44}$ Mujiyono Abdillah, Fikih Lingkungan, Panduan Spiritual Hidup berwawasan Lingkungan, (Yogyakarta; Akademi Manajemen Perusahaan YKPN, 2005), h. 23.
} 
Prinsip kedua, bahwa segala isi alam diberikan kepada manusia untuk melanjutkan kehidupannya. ${ }^{45}$ Prinsip ini didasarkan kepada penjelasan al-Qur'an:

"Dia-lah Allah, yang menjadikan segala yang ada di bumi untuk. kamu dan Dia berkehendak (menciptakan) langit, lalu dijadikan-Nya tujuh langit.dan Dia Maba mengetahui segala sesuatu”.

Prinsip ketiga, bahwa seluruh alam jagat raya ini tunduk kepada manusia. ${ }^{46}$ Prinsip ini didasarkan kepada penjelasan al-Qur'an:

"Allah-lah yang telah menciptakan langit dan bumi dan menurunkan air hujan dari langit, kemudian Dia mengeluarkan dengan air bujan itu berbagai buah-buahan menjadi rezki untukmu; dan Dia telah menundukkan babtera bagimu supaya babtera itu, berlayar di lautan dengan kehendak-Nya, dan Dia telah menundukkan (pula) bagimu sungai-sungai. Dan Dia telah menundukean (pula) bagimu matahari dan bulan yang terus menerus beredar (dalam orbitnya); dan telah menunduke.kan bagimu malam dan siang”.

Ayat ini yang membuat manusia untuk hidup bersahabat dengan lingkungan, karena lingkungan banyak memberikan manfaat bagi kelangsungan kehidupan manusia.Oleh sebab, itu manusia harus mengelolalanya tanpa merusak lingkungan tersebut.Prinsip keempat, adalah istikhlaf yang berarti manusia dititipkan amanah untuk mengurus dan melindungi bumi dan lingkungan hidup. ${ }^{47}$ Prinsip ini didasarkan kepada ayat al-Qur'an:

"Berimanlah kamu kepada Allah dan Rasul-Nya dan nafkabkanlah sebagian dari hartamu yang Allah telah menjadikan kamu menguasainya.Maka orang-orang yang beriman di antara kamu dan menafkabkan (sebagian) dari hartanya memperoleh pabala yang besar".

Prinsip kelima, bahwa manusia sebagai khalifah di muka bumi yang ditugaskan oleh Allah untuk membimbing dan memelihara serta melastarikan bumi (lingkungan hidup) demi tercapainya tujuan Allah dalam penciptaan alam semesata. ${ }^{48}$

Prinsip keenam, bahwa pemborosan harus dicegah walaupun berada dalam kebaikan. Prinsip ini berdasarkan ayat al-Qur'an:

"Dan berikanlah kepada keluarga-keluarga yang dekat akan baknya, kepada orang miskin dan orang yang dalam perjalanan dan janganlah kamu menghambur-bamburkan (hartamu) secara boros. Sesunggubnya pemboros-pemboros itu adalah saudara-saudara syaitan dan syaitan itu adalah sangat ingkar kepada Tubannya".

Prinsip ini sangat erat kaitannya dengan pemborosan dan keserakahan manusia pada zaman modern yang menggunakan teknologi secara berlebihan dan mengembangkan pola konsumtif pada taraf yang tak terkendali dan pada akhirnya mengakibatkan terjadinya krisis lingkungan.Prinsip ketujuh, bahwa kerusakan lingkungan hidup adalah akibat perbuatan manusia,

${ }^{45}$ H. A. Qadir Gassing HT, Etika Lingkungan Dalam Islam, (Jakarta, MAPAN, 2007), cet. 1, h. 111.

${ }^{46}$ Khaelany, Islam Kependudukan dan Lingkungan Hidup, (Jakarta; PT Rineka Cipta, 1995), h. 54.

${ }^{47}$ Seyyed Hossein Nasr, The Heart of Islam: Enduring Value for Humanity. diterjemahkan oleh Nurasiah Fakih Sutan Harahap, The Heart of Islam 'Pesan-Pesan Universal untuk Kemanusiaan, h. 16.

${ }^{48}$ Mujiyono Abdillah, Agama Ramah Lingkungan Dalam Perspektif Al-Qur'an, (Jakarta; Penerbit Paramadina, 2001), hal, 99. 
oleh karena itu manusia harus bertanggung jawab di dunia dan di akhirat. ${ }^{49}$ Prinsip ini didasarkan kepada ayat al-Qur'an:

"Telah nampak kerusakan di darat dan di laut disebabkan karena perbuatan tangan manusi, supay Allah merasakan kepada mereka sebahagian dari (akibat) perbuatan mereka, agar mereka kembali (ke jalan yang benar)".

Jadi konsekuensi dari perbuatan melakukan kerusakan itu, manusia harus bertanggung jawab di dunia, seperti sadar dan tidak mengulangi perbuatan yang sifatnya merusak lingkungan, memperbaiki lingkungan yang telah dirusaknya sehingga dapat berfungsi kembali untuk generasi yang akan datang, dan membayar ganti rugi, jika terdapat merugikan masyarakat dan negara. Sedangkan tanggung jawab di akhirat berupa sanksi yaitu dosa dan neraka.Jadi, seorang yang merusak lingkungan harus diberi sanksi, baik sanksi negara maupun sanksi agama.

Demikian prinsip etika pengelolaan lingkungan dalam Islam.Etika ini sangat bermanfaat untuk menyadarkan sifat manusia yang merusak dan harus ditanamkan dalam diri seorang yang beragama Islam dan pelestarian lingkungan.

\section{Metode Penelitian}

Dalam penelitian ini diperlukan data tentang pandangan dan sikap ulama Balangan terkait dengan eksplorasi sumber daya alam batubara di Kabupaten Balangan.Untuk mengumpulkan data tersebut, digunakan jenis penelitian lapangan (field research).Sedangkan sifat penelitian ini adalah penelitian kualitatif deskriptif.Adapun Penelitian ini menggambil lokasi di daerah Kabupaten Balangan Kalimantan Selatan..$^{50}$

Kemudian untuk subyek penelitian ini adalah para ulama yang berada di Kabupaten Balangan Kalimantan Selatan.Ulama yang dimaksud ialah ulama yang tergabung dalam organisasi MUI Kabupaten Balangan dan ulama yang mempunyai pengajian rutin, dan objek penelitian ini adalah mengenai pemahaman dan sikap para ulama yang tersebut diatas terkait dengan eksplorasi sumber daya alam batubara di Kabupaten Balangan Provinsi Kalimantan Selatan.

Selanjutnya, untuk teknik pengumpulan data dalam penelitian ini menggunakan wawancara dan dokumentasi, agar penulis bisa mendapatkan keterangan yang berhubungan dengan masalah yang diteliti dan mengumpulkan data-data yang mungkin tersimpan seperti dokumen, fotofoto dan sebagainya.

\section{Hasil Penelitian}

Dalam penelitian ini, penulis mengklasifikasikan dalam beberapa tema wawancara dengan ulama di Kabupatem Balangan, adapun tema-tema tersebut sebagai berikut:

1. Pandangan Ulama Tentang Aktifitas Pertambangan Batubara

2. Pandangan Ulama Terhadap Pemerintah Kabupaten Balangan

3. Pandangan Ulama Tentang Pengusaha Tambang

\footnotetext{
${ }^{49}$ H. A. Qadir Gassing HT, Etika Lingkungan Dalam Islam, cet. 1, h. 122.

${ }^{50}$ Koentjaraningrat, Metode-metode Penelitian Masyarakat, (Jakarta; PT Gramedia, 1983), h. 253.
} 
Ketika penulis mengadakan penelitian wawancara dengan ulama di Kabupaten Balangan, penulis menemukan beberapa kelompok yang memiliki perbedaan dalam pandangan atau pendapat terhadap aktivitas pertambangan di Kabupaten Balangan.Kelompok tersebut terdiri pro (mendukung), kontra (tidak mendukung), dan moderat (tidak ada kejelasan/mengambil jalan tengah).

\section{Pandangan Ulama Tentang Aktifitas Pertambangan Batubara}

Pertambangan batubara di daerah Balangan memberikan pengaruh yang sangat signifikan terhadap kehidupan masyarakat sekitar, terutama dalam bidang perekonomian dan kesejahteraan masyarakat serta menambah pendapatan asli daerah (PAD). Menurut pandangan ulama yang pro bahwa dengan adanya tambang batubara di Balangan memberikan kontribusi yang banyak, terutama dalam sektor perekonomian dan kesejahteraan rakyat dari segala bidang serta meningkatkan pendapatan asli daerah, menurut A HD hal ini sesuai dengan ayat al-Qur'an: ${ }^{51}$

"Dia-lah Allah, yang menjadikan segala yang ada di bumi untuk. kamu dan Dia berkehendak. (menciptakan) langit, lalu dijadikan-Nya tujuh langit dan Dia Maha mengetahui segala sesuatu".

"Dan Dia telah menunduk.kan untuk.mu apa yang di langit dan apa yang di bumi semuanya, (sebagai rabmat) daripada-Nya.Sesunggubnya pada yang demikian itu benar-benar terdapat tanda-tanda (kekuasaan Allab) bagi kaum yang berfikir".

Namun, kita harus mengingat bahwa kekayaan alam batubara ini sebuah sumber daya alam yang tidak dapat diperbarui. Jika dalam pengambilan batubara tidak secara arif dan bijaksana maka akan merusak alam yang berakibat bagi generasi yang akan datang, serta hancurnya ekosistem kehidupan yang berada di hutan atau pun kehidupan yang berada di perairan. diantara akibat dari kerusakan alam yang ditimbulkan oleh aktifitas tambang batubara ialah kerusakan hutan, kekurangan lahan, pencemaran lingkungan, hilangnya sumber mata air, dan lain-lain. Oleh sebab itu, sebagian ulama di Kabupaten Balangan kontra dengan adanya aktifitas tambang batubara. Kenyataan ini dipertegas dengan pernyataan salah satu ulama A Y yang kontra terhadap aktifitas dengan mengutip salah satu ayat dalam al-Qur'an yaitu: ${ }^{54}$

"Telah nampak kerusakan di darat dan di laut disebabkan karena perbuatan tangan manusi, supay Allah merasakan kepada mereka sebahagian dari (akibat) perbuatan mereka, agar mereka kembali (ke jalan yang benar). Katakanlab: "Adakanlah perjalanan di muka bumi dan perbatikanlah bagaimana kesudahan orang-orang yang terdabulu. kebanyakan dari mereka itu adalab orang-orang yang mempersekutukan (Allah)". ${ }^{55}$

${ }^{51}$ A HD, Wawancara Pribadi, Balangan, 04-11-2013.

${ }^{52}$ Dia-lah Allah, yang menjadikan segala yang ada di bumi untuk kamu dan Dia berkehendak (menciptakan) langit, lalu dijadikan-Nya tujuh langit. dan Dia Maha mengetahui segala sesuatu.

${ }^{53}$ Dan Dia telah menundukkan untukmu apa yang di langit dan apa yang di bumi semuanya, (sebagai rahmat) daripada-Nya. Sesungguhnya pada yang demikian itu benar-benar terdapat tanda-tanda (kekuasaan Allah) bagi kaum yang berfikir.

${ }^{54}$ A Y, Wawancara Pribadi, Balangan, 13-11-2013.

${ }^{55}$ Telah nampak kerusakan di darat dan di laut disebabkan karena perbuatan tangan manusia, supaya Allah merasakan kepada mereka sebahagian dari (akibat) perbuatan mereka, agar mereka kembali (ke jalan yang benar). 
Kemudian, diantara ulama di Kabupaten Balangan terdapat yang berpandangan moderat atau abu-abu, tidak membela dan tidak menyalahkan dengan aktifitas pertambangan, bahkan dari beberapa pendapatnya tidak memiliki kejelasan dan ketegasan terhadap aktifitas pertambangan batubara yang berada di Kabupaten Balangan. Seperi pandangan salah satu ulama yang moderat bahwa tidak terlalu mengetahui mengenai permasalahan pertambangan, karena tidak terlalu mendalami masalah tersebut. ${ }^{56}$

\section{Pandangan Ulama Terhadap Pemerintah Kabupaten Balangan}

Setiap perusahaan tambang tidak terlepas dari pengawasan pemerintah daerah sebagai penguasa daerah karena hukum pertambangan mineral dan batubara bersifat administrative, artinya saling berkaitan baik pemerintah ataupun pemerintah daerah karena mempunyai kedudukan yang lebih tinggi dalam proses pemberian izin, dalam pemberian izin tersebut didasarkan kepada syarat-syarat yang telah ditentukan dalam peraturan perundang-undangan. ${ }^{57}$

Dari hasil penelitian yang telah dilakukan oleh penulis, tidak ada pandangan para ulama Balangan yang bersikap pro terhadap kebijakan pemerintah terkait dengan perizinan tambangan batubara, mayoritas ulama berpandangan kontra terhadap kebijakan pemerintah, ini didasari karena mereka berpendapat bahwa pemerintah dari awal pembebasan lahan sampai pengelolaan batubara kurang mengawasi dengan baik dan masyarakat di dekat areal pertambangan belum merasakan secara keseluruhan keuntungan dari pertambangan tersebut. ${ }^{58}$

\section{Pandangan Ulama Tentang Pengusaha Tambang}

Pengusaha tambang batubara merupakan orang yang melakukan aktifitas pertambangan. Pengusaha tambang ini meliputi seluruh karyawan dalam perusahaan tambang tersebut. Dari hasil penelitian yang telah dilakukan bahwa terdapat pandangan ulama di Kabupaten Balanganpro dan kontra tentang pengusaha tambang batubara di daerah Balangan.

Ulama yang pro atau memihak kepada pengusaha tambang batubara, mereka berpandangan karena pengusaha tersebut sudah mendapat persetujuan dari pemerintah, dalam hal ini S A mengatakan bahwa:59 "Wajar mereka melakukan aktifitas pertambang karena sudah mendapatkan izin usaba tambang dari pemerintab".

Adapun ulama yang kontra dengan pengusaha tambang karena pengusaha tambang bekerja tidak sesuai dengan yang dikehendaki oleh masyarakat, sering teguran-teguran kita sampaikan dan diterimanya dengan baik. Namun, untuk realisasi dan implemantasinya di lapangan tidak mereka lakukan. ${ }^{60}$ Artinya pengusaha tambang tidak mengindahkan keinginan masyarakat.

\section{Analisis}

Berdasarkan sudut pandang eko-sufisme yang memandang kewajiban setiap individu untuk menjaga kelestarian alam semesta, maka eksplorasi dan pengelolaan bidang pertambangan

\footnotetext{
${ }^{56} \mathrm{LD}$, Wawancara Pribadi, Balangan, 06-11-2013.

${ }^{57}$ Salim H.S, Hukum Pertambangan Mineral \& Batubara, (Jakarta Timur, Sinar Grafika, 2012), h. 21.

${ }^{58} \mathrm{~S}$ A, Wawancara Pribadi, Balangan, 09-12-2013.

${ }^{59} \mathrm{~S}$ A, Wawancara Pribadi, Balangan, 09-12-2013.

${ }^{60}$ A Y, Wawancara Pribadi, Balangan, 13-11-2013.
} 
seharusnya perlu diserasikan antara pemanfataan energi dan devisa yang dihasilkan dari pertambangan batubara, dengan upaya untuk memperbaiki kerusakan lahan yang telah ditimbulkan, serta upaya konservasi lingkungan dari pencemaran yang telah terjadi.

Pengendalian terhadap bahaya pencemaran lingkungan dan perubahan keseimbangan ekosistem harus menjadi perhatian serius pihak-pihak yang bertanggung jawab, sebagai bagian yang tak terpisahkan dari upaya manusia meningkatkan kualitas hidupnya dan menjaga alam semesta sebagai teofani dan ayat-ayat Tuhan disisi yang lainnya.

Selain itu, manusia sebagai khalifah di muka bumi bertugas untuk menjaga, memelihara dan memanfaatkan alam semesta pada dasarnya untuk menjalin huungan yang harmonis antara Tuhan, alam dan manusia. Namun kenyataan yang telah terjadi saat ini masih jauh dari apa yang diharapkan, kehadiran perusahaan tambang di suatu daerah yang diharapkan mampu memberikan kesejahteraan bagi masyarakat disekitarnya, seringkali membuat warga menderita akibat kehilangan lahan pencaharian, adat, dan dampak kerusakan lingkungan yang akan dirasakan. Hal ini disebabkan karena budaya konsumtif pada diri manusia untuk mengambil kekayaan alam tanpa mempertimbangkan dampak positif dan negatif yang akan terjadi.

Oleh sebab itu, dalam konsep eko-sufisme memberikan suatu tawaran untuk meminimalisir budaya konsuntif yang ada pada diri manusia dengan cara menanamkan sifat zuhd, dengan adanya sifat zubd dalam diri manusia akan melatih seseorang agar tidak terlalu berlebihan mengonsumsi dan menggunakan sesuatu yang sifatnya material, selain itu, sifat zubd akan bisa meminimalisir budaya konsumtif dalam waktu jangka panjang. Zuhd disini bukan hanya diartikan sebuah konsep dalam tasawuf, akan tetapi sebuah perwujudan yang harus diterapkan dalam kehidupan sehari-hari.

\section{Penutup}

Dari hasil penelitian ini dapat diambil kesimpulan bahwa terdapat beberapa pandangan ulama yang berbeda terhadap aktifitas pertambangan batubara, pemerintah dan pengusaha tambang itu sendiri menurut sudut pandangan eko-sufisme. Perbedaan pandangan tersebut ialah pro yaitu ulama yang mendukung sepenuhnya akan adanya tambang batubara, kontra yaitu ulama yang tidak mendukung dengan adanya tambang batubara, dan moderat atau abuabu yaitu ulama yang mengambil jalan tengah, tidak membela dan menyalahkan siapapun, pendapatnya tidak mempunyai kejelasan dan ketegasan.

Ulama yang mendukung terhadap aktifitas pertambangan patut dihargai karena mereka berpandangan untuk kesejahteraan masyarakat. Namun mereka yang menyetujui tidak menghiraukan etika lingkungan.Adapun pandangan ulama yang kontra terhadap aktifitas pertambangan batubara khususnya aktivitas pertambangan yang tidak mengindahkan kaidahkaidah dan prinsip keseimbangan lingkungan dan tidak berlandas jangka panjang, mereka yang menjaga etika lingkungan sesuai dengan konsep dalam eko-sufisme.

\section{Saran-saran}

Berdasarkan hasil kesimpulan penelitian di atas penulis memberikan beberapa saran antara lain : 
1. Adanya tindakan ulama dalam menyikapi permasalahan pertambangan batubara di Kabupaten Balangan.

2. Dilakukannya revisi ulang terhadap kebijakan-kebijakan pemerintah daerah Kabupaten Balangan yang mencoba menggali pendapatan asli daerah (PAD) melalui pemanfataan sumber daya alam yang ada khsusnya sumber daya alam batu bara.

3. Dilakukannya peninjauan kembali terhadap izin-izin pertambangan yang diberikan kepada perusahaan-perusahaan pertambngan yang beroperasi diwilayah Kabupaten Balangan.

4. Dilakukannya negosiasi ulang terhadap pihak perusahaan pertambangan batubara dalam hal dana royalti dan perimbangan dari laba usaha pengerukan batubara di wilayah Kabupaten Balangan.

5. Pemanfaatan pendapatan asli daerah kabupaten balangan dari hasil royalti pertambangan batubara untuk menciptakan dan membangun sumber-sumber penghasil ekonomi yang bersifat jangka panjang dan berkelanjutan sehingga pemerintah tidak akan kelabakan jika seandainya pertambangan batubara dihentikan akibat habisnya sumber daya alam batubara yang ada.

6. Peningkatan usaha untuk memperbaiki pendapatan asli daerah (PAD) lewat sumber-sumber lain yang tidak merusak alam dan berkelanjutan seperti meningkatan aspek pariwisata, perkebunan, peternakan dan perdagangan

7. Pemberhentian aktivitas pertambangan batubara jika pemerintah daerah dalam hal ini pemerintah daerah Kabupaten Balangan merasa bahwa sumber pendapatan asli daerah (PAD) lain yang mereka bangun tersebut dirasa sudah cukup untuk menjalankan roda pemerintahan dan ekonomi Kabupaten Balangan.

\section{DAFTAR PUSTAKA}

Thalhah, Ahmad Mufid, (2008). Fiqh Ekologi Menjaga Bumi Memahami Makna Kitab Suci, Yogyakarta: Total Media.

Ibrahim Abdul-Matin, (2012). Greendeen Inspirasi Islam Dalam Menjaga dan Mengelola Alam, Cet. ke-1, Jakarta: Mizan.

Ulfah Utami, (2008). Konservasi Sumber Daya Alam perspektif Islam dan Sains, , Cet. ke-1, Malang: UIN Malang Press.

Rachmad K Dwi Susilo, (2008). Sosiologi Lingkungan, Jakarta: Raja Grafindo Perkasa.

Suwito NS, (2011). Eko Sufisme, Konsep Strategi dan Dampak, Purwokerto: Stain Press.

Amos Neolaka, (2008). Kesadaran Lingkungan, Cet. ke-1, Jakarta: Rineka Cipta.

Tim Peneliti, Eko-Teologi Al-Qur'an "Sebuah Kajian Tafsir dengan Pendekatan Tematik”, Banjarmasin: IAIN Antasari Banjarmasin.

Tresna Sastrawijaya, (2009). Pencemaran Lingkungan, Jakarta: Rineka Cipta.

Sukarni, (2011). Fiqh Lingkungan Hidup Perspektif Ulama Kalimantan Selatan, Jakarta: Kementrian Agama RI.

H. Salim, (2012). Hukum Pertambangan Mineral Batubara, Jakarta: Sinar Grafika.

Ahmad Bangun Nasution dan Riyani Harum Siregar, (2013). Akblak Tasawuf, Jakarta: Raja Grafindo Perkasa.

Amin Syukur dan Masyharuddin, (2002). Intelektualisme Tasannf, Yogyakarta: Pustaka Pelajar. 
Ali Maksum, Tasawnf Sebagai Pembebasan, Yogyakarta; Pustaka Pelajar, 2003.

Seyyed Hossein Nasr, (1997). Pengetahuan dan Kesucian, Yogyakarta: Pustaka Pelajar.

Mudhofir Abdullah,(2010). Al-Qur'an dan Konservasi Lingkungan, Jakarta: Penerbit Dian Rakyat. Drajat Amroeni, (2005). Subrawardi "Kritik Filsafat Prepatitik", Yogyakarta: LKIS.

Yunasril Ali,(1997). Manusia Citra Ilah, Pengembangan Konsep Insan kamil Ibn Arabi oleh Al-jilli, Jakarta: Penerbit Paramadina.

Sachiko Murata, (2000). The Tao of Islam, Jakarta: Penerbit Mizan.

Sukarni, (2011). Fikih Lingkungan Hidup Perspektif Ulama Kalimantan Selatan, Cet. 1, Jakarta: Kementrian Agama RI.

Mujiyono Abdillah, (2001). Agama Ramah Lingkungan Dalam Perspektif Al-Qur'an, Jakarta: Penerbit Paramadina. 